\title{
ANALISIS PERBEDAAN KINERJA AKIBAT DAMPAK PERUBAHAN TEKNOLOGI PADA UNIT INTERNATIONAL ROAMING PADA PERUSAHAAN TELEKOMUNIKASI PT XYZ
}

\author{
PERFORMANCE DIFFERENCES ANALYSIS DUE TO THE IMPACT OF TECHNOLOGY CHANGES \\ IN THE INTERNATIONAL ROAMING UNIT IN TELECOMMUNICATION COMPANY PT XYZ
}

\author{
Tendy Arya Pranata ${ }^{*}$, Arif Imam Suroso*), dan Irman Hermadi ${ }^{* *)}$ \\ *) Sekolah Bisnis, IPB University (SB-IPB) \\ Jl. Raya Pajajaran Bogor 16151 \\ ${ }^{* *}$ Departement Ilmu Komputer, Fakultas Matematika dan Ilmu Pengetahuan Alam, IPB University \\ Jl. Meranti, Kampus IPB Darmaga, Bogor 16680
}

\begin{abstract}
Technological changes impacts changes in behavior and work systems carried out by the organization. The company's investment in new technology should be able to increase revenue, but PT XYZ's revenue growth tends to be stagnant. Therefore, the central management designs an assessment measure that could be used to evaluate a unit's performance. This study aimed to analyze the differences in the international roaming unit's performance due to technological changes using the learning \& development, customers, internal business processes, and financial approach. Also, it aimed to initiate recommendations to improve the performance of international roaming units due to technological changes. The data used were secondary data from internal companies, while the methods used were descriptive, Balanced Scorecard (BSC), and paired test. The result obtained was that security criteria had a real difference in the impact of technology adoption on the learning \& development indicator. There were significant differences in the business process indicator due to technological change. There was no significant difference in the impact of technology adoption in terms of the customer and financial indicators. The international roaming unit needs to optimize technology adoption further.
\end{abstract}

Keywords: balanced scorecard, organinternational roaming, technology adoption, performance, paired test

\begin{abstract}
Abstrak: Investasi perusahaan pada sebuah teknologi baru seharusnya mampu meningkatkan pendapatan perusahaan, namun faktanya pertumbuhan pendapatan PT XYZ cenderung stagnan. Oleh karena itu, manajemen pusat merancang suatu ukuran penilaian yang dapat digunakan sebagai dasar dalam menilai kinerja suatu unit. Adanya perubahan teknologi memberikan dampak pada perubahan perilaku kerja dan system kerja yang dilakukan oleh organisasi. Penelitian bertujuan untuk menganalisis perbedaan kinerja unit internasional roaming dengan pendekatan learning \& development, customer, internal business process, dan financial akibat perubahan teknologi. Serta, menginisiasi rekomendasi untuk meningkatkan kinerja unit internasional roaming akibat perubahan teknologi. Data yang digunakan adalah data sekunder yang berasal dari internal perusahaan, sedangkan metode yang digunakan adalah deskriptif, Balanced Scorecard (BSC), dan paired test. Hasil penelitian diperoleh kriteria keamanan memiliki perbedaan nyata dampak adopsi teknologi pada indicator learning \& development. Terdapat perbedaan nyata pada indicator business proses akibat dari perubahan teknologi. Pada indicator customer dan finansial tidak terdapat perbedaan nyata dampak dari adopsi teknologi. Unit roaming internasional perlu lebih mengoptimalkan adopsi teknologi.
\end{abstract}

Kata kunci: Adopsi teknologi, balanced scorecard, jelajah internasional, kinerja, uji berpasangan

${ }^{1}$ Corresponding author:

Email: tendy.arya@gmail.com 


\section{PENDAHULUAN}

Pesatnya pertumbuhan teknologi informasi dan komunikasi di Indonesia memberikan dampak besar bagi dunia bisnis, kesehatan, keuangan, transportasi, dan lainnya. Jumlah penggunaan smartphone dari tahun ketahun terus mengalami peningkatan dimana tahun tahun 2018 telah mencapai 83.5 juta pengguna dan tahun 2019 sebanyak 92 juta pengguna (Databoks, 2016). Hal ini disebabkan kebutuhan serta gaya hidup masyarakat yang cenderung praktis dan serba cepat sehingga berdampak pada seluruh aspek kehidupan. Oleh karena itu, aktivitas yang diharapkan masyarakat terkait penggunaan teknologi komunikasi adalah kecepatan, keamanan dan kekuatan dari jaringan.

Sejalan dengan perkembangan teknologi, para pelaku bisnis dan ilmuwan terus melakukan inovasi dalam pengembangangenerasiteknologiinformasikomunikasi yang dimulai pada generasi ke-1 (1G) pada tahun 1979 hingga generasi ke-5 (5G) pada tahun 2019. Saat ini sedang mulai dikenalkan generasi baru teknologi generasi ke 5 yang dipastikan memiliki kinerja lebih baik dari pada generasi-generasi sebelumnnya. Disisi lain, perubahan generasi teknologi informasi memaksa banyak pihak untuk ikut melakukan perubahan pada perangkat atau device yang dapat mendukung perubahan tersebut.

PT XYZ merupakan salah satu perusahaan yang menyediakanjasatelekomunikasikepadaparapelanggan di Indonesia dan beberapa negara yang masuk dalam kerjasama PT XYZ terus berusaha menambah jumlah mitra perusahaan telekomunikasi lain yang berada di negara lain dalam rangka memenuhi kebutuhan para pelanggan yang melakukan perjalanan ke luar negeri. Adanya perubahan teknologi memberikan dampak pada perubahan perilaku kerja dan system kerja yang dilakukan oleh organisasi. Gafar (2017) menjelaskan bahwa suatu perubahan teknologi mampu merubah suatu sistem berlaku. Hasil evaluasi manajemen PT $\mathrm{XYZ}$ diperoleh terdapat perubahan pendapatan setelah dilakukan adopsi teknologi baru. Diketahui bahwa terjadi fluktuasi pertumbuhan pendapatan perusahaan namun cenderung stagnan. Hal ini menunjukan bahwa investasi teknologi Network Traffic Redirection tidak mampu secara langsung meningkatkan pendapatan perusahaan. Dilain sisi, dengan implementasi teknologi maka operational cost dipastikan menurun. Menanggapi masalah ini, manajemen pusat merancang suatu ukuran penilaian yang dapat digunakan sebagai dasar dalam menilai kinerja suatu unit. Penggunaan balanced scorecard dianggap merupakan bagian yang mampu dijadikan untuk menyusun perubahan penilaian.

Menurut Subaktilah et al. (2018), faktor internal dan eksternal penting untuk diketahui untuk memberikan pandangan serta mengoptimalkan kinerja perusahaan. Pandangan internal memandang seluruh bagian dalam perusahaan adalah bagian penting yang mampu mendorong bisnis menjadi lebih baik meliputi (aspek sumberdaya manusia, keuangan, teknis, pemasaran), sementara eksternal terkait dengan kebijakan pemerintah, sosial, budaya dan ekonomi (Riyanto, 2018).

Menurut Putri dan Sahadak (2019), pergantian teknologi berdampak baik terhadap peningkatan kemampuan kerja. Salah satu metode penilaian suatu kinerja perusahaan dapat dilakukan dengan metode balanced scorecard. Iranzadeh et al. (2017) menjelaskan, model balanced scorecard adalah metode untuk mengevaluasi dan mengendalikan program dengan konsistensi yang memadai namun diperlukan uji statistik tambahan jika perusahaan telah memiliki penilaian kinerja tersendiri, dalam kajiannya diketahui bahwa pengaruh pembelajaran berperan penting dalam bisnis.

Harumantaka et al. (2019), menggunakan balanced scorecard sebagai alat analisis manajemen strategis untuk membantumenentukan kinerja jangka panjang dari suatu organisasi. Penelitian dilakukan dengan menggambarkan visi, misi, dan motto Perusahaan menjadi tujuan strategis, menetapkan indikator kinerja utama, dan merancang sistem evaluasi kinerja berbasis Balanced Scorecard (BSC). Matriks IFE dan EFE digunakan untuk mengevaluasi faktor-faktor utama dari kekuatan dan kelemahan perusahaan serta merumuskan strategi. Indriani et al. (2017) menggunakan empat perspektif dalam analisis balanced scorecard, yaitu perspektif keuangan, perspektif pelanggan, perspektif proses bisnis internal, dan perspektif pertumbuhan dan pembelajaran. Chimtengo et al. (2017) memberikan gambaran mengenai evaluasi menggunakan balanced scorecard harus dimulai dengan melakukan pemantauan dan evaluasi pada staff, hal ini menandakan bahwa kemampuan pegawai sangat dipentingkan dalam mengembangkan organisasi. 
Pada dasarnya ukuran kinerja merupakan produk turunan dari visi misi. Menurut Wadha dan Parimoo (2016), visi dan misi menciptakan awal dari sebuah organisasi dan hasil akhir atau outcome adalah kinerja secara keseluruhan. Sebuah organisasi dibentuk dengan menetapkan visi dan misinya kemudian segala upaya dilakukan untuk pencapaiannya. Menurut Namun (2015), penilaian lingkungan internal dan eksternal dianggap sebagai manajemen alat yang digunakan dalam perencanaan strategis dan penyelesaian masalah untuk menetapkan prioritas dan arah masa depan.

Saatini penggunaan balancedscorecard terus digunakan untuk mengukur aktivitas dari unit internasional roaming, melalui pendekatan ini diharapkan kinerja perusahaan dapat terus meningkat. Kondisi ini juga menuntut kesiapan setiap pegawai dalam melayani dan menjalankan fungsi dari tiap divisinya, mengembangkan proses bisnis internal yang baik, agile, dan adaptable. Atas dasar permasalahan tersebut, penelitian ini bertujuan menganalisis perbedaan kinerja unit internasional roaming dengan pendekatan learning \& development akibat perubahan teknologi; menganalisis perbedaan kinerja unit internasional roaming dengan pendekatan internal business process akibat perubahan teknologi; menganalisis perbedaan kinerja unit internasional roaming dengan pendekatan customer akibat perubahan teknologi; menganalisis perbedaan kinerja unit internasional roaming dengan pendekatan financial akibat perubahan teknologi; menganalisis rekomendasi untuk meningkatkan kinerja untuk unit internasional roaming akibat perubahan teknologi.

\section{METODE PENELITIAN}

Penelitian dilakukan di PT XYZ dengan basis bisnis telekomunikasi di Indonesia. Waktu penelitian dilakukan sejak bulan April hingga Oktober 2019. Data primer didapatkan dari wawancara yang dibantu dengan kuesioner terbuka kepada para responden. Adapun sumber data sekunder berasal dari laporan operasional perusahaan selama dua tahun (2017-2019), studi literature, penelitian terdahulu serta sumber kredibel lainnya. Desain penelitian yang digunakan dalam penelitian adalah case study, dimana mengambil issue terkait dengan kasus perubahan teknologi.

Metode pengambilan sampel yang digunakan dalam penelitian ini adalah convenience sampling, dimana ditujukan untuk memberikan kenyamanan kepada seluruh pihak yang terlibat. Sampel merupakan para karyawan yang bekerja pada PT XYZ dan terlibat langsung dengan issue tersebut, adapun jumlah sampel sebanyak 30 orang. Sugiyono (2010) menjelaskan bahwa pengambilan sampel minimal 30 orang untuk memenuhi jumlah sampel terbaik serta memenuhi sebaran normal dalam proses pengambilan data. Metode analisis data penelitian dilakukan dengan menggunakan analisis deskriptif, balance scorecard, dan uji beda.

Penilaian kinerja perusahaan dilakukan dengan metode Balanced Scorecard, yaitu dengan mempertimbangkan empat perspektif untuk mengukur kinerja perusahaan yaitu: perspektif finansial, pelanggan, proses bisnis internal serta proses pembelajaran dan pertumbuhan (Kaplan dan Norton, 2000). Konsep penetapan sasaran dalam perusahaan dengan balance scorecard harus memiliki memperhatikan tiap tahap dengan seksama yang dijabarkan dengan cara 1) memperjelas dan menerjemahkan visi dan strategi; 2) merencanakan, menetapkan, dan menyelaraskan sasaran; 3) meningkatkan umpan balik dan pembelajaran strategis.

Selanjutnya, dilakukan identifikasi kondisi internal dan eksternal perusahaan. Kedua aspek ini dikaji karena terdapat perbedaan aspek serta cara pandang yang mampu mempengaruhi kondisi bisnis perusahaan. Identifikasi aspek internal perusahaan dilakukan dengan analisis value chain. Hidayati dan Akbar (2019) menjelaskan bahwa value chain dapat digunakan sebagai dasar dalam mengetahui kondisi internal suatu usaha. Penggunaan value chain pada kajian ini hanya terbatas pada pendekatan deskriptif melalui aktivitas utama dan pendukung perusahaan.

Identifikasi aspek eksternal dilakukan dengan pendekatan Porter Five Forces. Menurut Porter (2008), kesadaran dari lima kekuatan Porter dapat membantu perusahaan memahami struktur industri dan mengintai posisi yang lebih menguntungkan serta posisi yang rentan terhadap serangan. Terdapat lima kekuatan Porter, yaitu kekuatan pemasok, kekuatan pembeli, persaingan antar perusahaan sejenis, masuknya pesaing baru, dan masuknya produk subtitusi.

Untuk mengkaji kesesuaian perubahan teknologi dilakukan uji beda atau paired sample t-test, ditandai adanya perbedaan rata-rata pada indikator-indikator penilaian kinerja sebelum dan rata-rata sesudah diberikan perlakuan. Model uji beda ini digunakan untuk menganalisis model penelitian pre-post atau 
sebelum dan sesudah. Pre-post terkait dengan deskripsi kinerja organisasi saat menggunakan teknologi lama sementara sesudah terkait dengan deskripsi kinerja organisasi setelah menggunakan teknologi. Uji beda digunakan untuk mengevaluasi perlakuan (treatment) tertentu pada satu sampel yang sama pada dua periode pengamatan yang berbeda (Pramana, 2012). Dasar pengambilan keputusan untuk menerima atau menolak Ho pada uji ini adalah sebagai berikut.

1. Jika $t$ hitung $>t$ tabel dan probabilitas (Asymp.Sig) $<0,05$, maka Ho ditolak dan Ha diterima.

2. Jika $t$ hitung $<\mathrm{t}$ tabel dan probabilitas (Asymp.Sig) $>0,05$, maka Ho diterima dan Ha ditolak.

Pada kasus penelitian unit internasional roaming melakukan investassi berupa adopsi teknologi baru dalam rangka meningkatkan performance dalam segala aspek. Manajemen PT XYZ perlu mengetahui bahwa keputusan investasi tersebut sesuai dan berdampak pada peningkatan kinerja perusahaan secara umum, dengan menggunakan ukuran kinerja yang telah ada, digunakan sebagai dasar untuk mengetahui seberapa jauh perubahan tersebut. Penelitian diawali dengan identifikasi kondisi internal dan eksternal secara deskriptif. Selain itu, dilakukan pengukuran kinerja akibat adanya adopsi teknologi dengan melakukan uji beda pada empat indikator kinerja, yaitu pengembangan dan pembelajaran, pelanggan, finansial, dan proses bisnis internal. Hasil analisis menghasilkan implikasi manajerial yang dapat digunakan oleh perusahaan untuk strategi mengoptimalkan keputusan perubahan teknologi yang digunakan untuk unit internasional roaming dan PT XYZ.

\section{HASIL}

\section{Gambaran Umum PT XYZ}

PT XYZ adalah salah satu perusahaan penyedia jasa telekomunikasi dan jaringan telekomunikasi di Indonesia. Perusahaan ini menawarkan saluran komunikasi untuk pengguna telepon genggam dengan pilihan pra bayar maupun pascabayar; jasa lainnya yang disediakan adalah saluran komunikasi via suara untuk telepon tetap (fixed) termasuk sambungan langsung internasional IDD (International Direct Dialing), serta jasa nirkabel. Perusahaan ini juga menyediakan layanan multimedia, internet, dan komunikasi data (MIDI= Multimedia, Internet \& Data Communication Services).
Visi dari PT XYZ menjadi perusahaan telekomunikasi digital terdepan di Indonesia. Adapun misi dari PT XYZ tergambarkan melalui beberapa point seperti: 1) Lampaui batasan untuk menghasilkan kinerja terbaik bersama tim yang kuat; 2)Eksekusi pembangunan jaringan berkualitas video yang kompetitif; 3) Aktivasi percepatan business to business sebagai mesin pertumbuhan baru; 4) Mendapatkan kepercayaan dan berikan layanan terbaik dengan kualitas \& harga sepadan. Dalam hal ini visi misi tidak mengalami perubahan namun setiap aktivitas strategis harus didasarkan pada visi misi organisasi.

Nilai-nilai dari PT XYZ dikembangkan untuk memberikan tambahan dasar untuk mencapai visi perusahaan: 1) Terpercaya, berpikir positif, konsisten dalam perkataan dan perbuatan yang terpuji serta dapat diandalkan; 2) tekad menjadi yang terbaik, semangat mencapai keunggulan dengan melakukan perbaikan dan penyempurnaan berkesinambungan; 3) Cepat, sigap dalam memecahkan masalah, mengambil keputusan, bertindak dan beradaptasi; 4) Berjiwa muda, enerjik, dinamis, dan berani menjadi penggerak perubahan; 5) Peduli, menunjukkan perhatian, menghargai, serta melayani sepenuh hati.

Unit internasional roaming merupakan bentuk layanan dasar untuk pelanggan terkait dengan telekomunikasi global. Unit internasional roaming dari PT XYZ yang baik dan optimal akan menjadikannya bisnis global yang dapat menjadi tambahan revenue bagi suatu operator. Pelayanan dari unit internasional roaming ini telah lama diberikan oleh PT XYZ kepada pelanggan tetapi pengelolaan untuk mewujudkan bisnis global yang bisa menjadi revenue center bagi operator belum dilakukan dengan optimal.

Hal ini dapat dilihat dari belum dilakukannya terobosanterobosan pengembangan untuk meningkatkan pelayanan. Bisnis ini akan selalu berkembang sebagai bisnis global tidak hanya pada service voice dan SMS saja, tetapi akan terus mengikuti perkembangan teknologi komunikasi seluler seperti GPRS/MMS, CAMEL, EDGE, dan UMTS. Kondisi ini menuntut operator untuk dapat menerapkan kerjasama unit international roaming sesuai dengan level service yang ada dan harus dapat bekerja sama dengan operator yang memiliki frekuensi dan teknologi yang berbeda. Kebijakan manajemen pada suatu unit operator seluler untuk menangani, mengelola dan mengembangkan bisnis global unit internasional roaming. 
Aktivitas unit internasional roaming bertujuan agar setiap operator tetap dan semakin bertahan (survive) dalam menghadapi tantangan, ancaman dan sekaligus dapat mengambil peluang yang ada saat pertumbuhan jumlah pelanggan seluler di Indonesia menurun. Penanganan bisnis ini melibatkan hampir dari semua unit, mulai dari frontliner hingga teknisi atau operator dan juga melibatkan level management setingkat direksi hingga dengan customer service. Hal ini menunjukkan bahwa bisnis ini adalah suatu bisnis besar yang melibatkan banyak pihak. Oleh karena itu diperlukan suatu strategi dan kebijakan yang tepat untuk menangani bisnis international roaming ini.

\section{Identifikasi Internal dan Eksternal}

Kotler (2009) menjelaskan bahwa aspek internal dalam organisasi dapat dikaji dengan melihat kekuatan dan kelemahan, sementara aspek eksternal dapat dilihat dari peluang dan ancaman yang dapat berdampak pada seluruh organisasi. Analisis internal dijabarkan melalui aktivitas utama dan aktivitas pendukung perusahaan. Terdapat lima kategori umum pada aktivitas utama yang pada setiap kategori terbagi menjadi beberapa aktivitas antara lain inbound logistic, operations, outbound logistic, sales \& marketing, dan services. Analisis eksternal perusahaan di deksripsikan melalui analisis lima kekuatan porter. Pada penelitian deskrispsi internal dan eksternal didapatkan dengan cara melakukan wawancara kepada karyawan.

Identifikasi yang telah dilakukan kemudian disusun untuk lebih memfokuskan terhadap empat point penting (kekuatan, kelemahan, peluang dan ancaman). Identifikasi internal di gambarkan dari hasil analisis kekuatan dan kelemahan, sedangkan analisis eksternal dari hasil analisis peluang dan ancaman. Adapun hasil gambaran kekuatan, kelemahan, ancaman dan peluang disajikan pada Tabel 1.

\section{Indikator Kinerja pada Unit Internasional Roaming}

Indikator kinerja dari unit internasional roaming pada dasarnya telah dirumuskan dan telah dimiliki oleh manajemen PT XYZ. Indikator-indikator penilaian yang telah dimiliki manajemen PT XYZ menggunakan pendekatan balanced scorecard, dimana memandang dalam beberapa aspek seperti learning and development, costumer, internal business process dan financial. Penjabaran dilakukan untuk mengetahui bahwa indikator penilaian masih sesuai dengan kondisi saat ini.

\section{a. Indikator Learning and Development}

Indikator learning and development menjadi bahan pertama yang dilakukan pengujian adanya perbedaaan akibat adanya adopsi teknologi yang dilakukan. Pada kajian ini seluruh data telah dimiliki oleh perusahaan, sehingga data yang digunakan bersifat data sekunder. Data yang diperoleh dari unit internasional roaming selanjutnyadiolahsehingga dapatmemberikaninformasi yang lebih berguna terkait dampak peningkatan dari adopsi teknologi. Resistance to change yang tinggi dari adopsi teknologi pada karyawan berdampak pada kinerja unit yang tidak meningkat.

Penurunan ini terjadi disebabkan karena adanya perbedaan pandangan dari pegawai atas kebijakan manajemen untuk mengadopsi teknologi. Para pegawai yang menjalankan aktivitas cenderung hanya mengikuti keputusan yang telah ditentukan. Pegawai pada mulanya menolak adanya adopsi teknologi, hal ini disebabkan karena mereka tidak sadar akan kebutuhan dalam mengupdate knowledge, skill, dan motivasi untuk selalu unggul dari pegawai yang lain. Penolakan juga disebabkan oleh ketakutan para pegawai akan adanya pengurangan jumlah pegawai yang akhirnya membuat dirinya tidak aman. Mengetahui hal tersebut manajemen berusaha untuk memberikan kesadaran melalui pendekatan manajemen perubahan kepada pegawai di unit internasional roaming. Pengujian secara statistik perlu dilakukan untuk mengetahui tingkat perbedaan nyata yang pada akhirnya berdampak terhadap kebijakan manajemen dalam mengelola sumberdaya yang dimiliki. Adapun informasi disajikan pada Tabel 2.

Manajemen dapat fokus untuk menurunkan resistance to change dari kriteria keamanan. Kriteria keamanan dipandang penting disebabkan karena pada dasarnya setiap individu berharap untuk diberikan rasa aman terhadap aktivitas yang dilakukan dimanapun khususnya tempat kerja. Hendarto dan Prihastuty (2014) mengatakan bahwa perusahaan perlu memberikan gambaran bahwa aktivitas yang dilakukan masih dengan aturan sesuai sehingga perusahaan dan seluruh entitasnya akan aman. 
Tabel 1. Identifikasi internal dan eksternal

\begin{tabular}{llll}
\hline Kekuatan & Kelemahan & Peluang & Ancaman \\
\hline $\begin{array}{l}\text { Teknologi IOT yang } \\
\text { komprehensif }\end{array}$ & Kurang Resource & Penggunaan data internet & Pindahnya subscriber \\
$\begin{array}{l}\text { Jumlah patner yang ada di } \\
400 \text { negara }\end{array}$ & $\begin{array}{l}\text { Response pelayanan yang } \\
\text { kurang }\end{array}$ & Regulasi kominfo & Produk subtitusi \\
$\begin{array}{l}\text { Hubungan yang baik antara } \\
\text { pegawai }\end{array}$ & Jumlah postpaid & Event & Perang tarif \\
$\begin{array}{l}\text { Kompetensi dan pengalaman } \\
\text { yang baik dalam } \\
\begin{array}{l}\text { internasional roaming. } \\
\text { Mencapai target kinerja }\end{array}\end{array}$ & Kualitas jaringan & Target pemerintah & Penetapan tarif pemerintah \\
\hline
\end{tabular}

Tabel 2. Uji sebelum dan sesudah adopsi teknologi beda pada resistance to change

\begin{tabular}{lcccl}
\hline Kriteria & Sebelum & Sesudah & Asymp.Sig (Pearson Chi-Square) & Kesimpulan $(<0.05)$ \\
\hline Kemauan & 3.81 & 4.13 & 0.504 & Tidak terdapat perbedaan \\
Keamanan & 3.56 & 4.32 & 0.027 & Terdapat perbedaan \\
\hline
\end{tabular}

Hasil uji tingkat kompetensi unit Internasional Roaming atas adopsi teknologi terhadap 16 karyawan menunjukkan peningkatan nilai kompetensi secara umum. Kondisi menandakan bahwa terjadi peningkatan pada kedua divisi yang berada di unit internasional roaming. Pada mulanya kompetensi pegawai sebelum adanya adopsi teknologi sebesar 3,70 berdasarkan penilaian dari manajemen pusat, sementara dengan adanya adopsi teknologi memberikan dampak pada peningkatan kompetensi menjadi 4,33. Temuan tersebut semakin membuktikan bahwa adopsi teknologi secara tidak langsung mampu mendorong para pegawai untuk meningkatkan kemampuannya.

Hasil uji beda pada kompetensi sebelum dan sesudah adopsi teknologi menunjukkan bahwa tidak ditemukan adanya perbedaan nyata dari kriteria knowledge dan skill namun secara umum ditemukan adanya perbedaan. Kondisi ini menunjukkan bahwa manajemen cukup untuk memberikan arahan untuk terus mengembangkan kompetensi melalui instrumen yang telah tersedia dalam perusahaan. Pemimpin unit internasional roaming dituntut untuk terus mengembangkan kompetensi pada knowledge dan skill pegawai. Kompetensi pegawai dipandang sebagai bentuk profesionalitas untuk mencapai tujuan organisasi, hal ini disebabkan bahwa organisasi memerlukan dukungan dari pegawai yang mampu bersama-sama mencapai tujuan tersebut (Dudin et al. 2017). Menurut Rocha et al. (2017) model manajemen berbasis kompetensi diyakini dapat membantu perusahaan dalam meraih kemungkinan sukses yang lebih tinggi. Kompetensi teknis dan perilaku diharapkan menjadikan individu sukses dalam organisasi, baik itu sekolah, universitas, atau tempat kerja (Decius dan Schaper, 2017; Getha-Taylor et al. 2016; Gómez-Arizaga et al. 2016)

Temuan adanya perbedaan nyata pada kedua pengukuran menandakan bahwa adopsi teknologi dipandang sebagai bagian penting yang harus dilihat oleh manajemen pusat sebagai bentuk adanya proses untuk mencapai tujuan organisasi serta ketepatan dalam keputusan adopsi teknologi baru. Manajemen perlu terus meningkatkan keyakinan rasa aman pada pegawai akibat dampak dari adopsi teknologi serta meningkatkan kompetensinya. Perusahaan dapat melakukan pelatihan dalam rangka peningkatan kemampuan dan pengetahuan karyawan akan teknologi baru. Perusahaan dapat memberikan himbauan bahwa setiap karyawan harus berkomitmen untuk terus mengupdate diri agar tetap dapat mencapai tujuan perusahaan. Pelatihan bukan hanya bersifat memberi tahu, namun dapat dilakukan dengan dummy implementation sampai karyawan merasa paham dan aman. Karyawan yang dapat mengupgrade dirinya menunjukkan bahwa dirinya merupakan masa depan perusahaan.

\section{b. Indikator Internal Business Process}

Indikator internal business process merupakan bentuk penilaian selanjutnya yang perlu dievaluasi oleh manajemen pusat terkait dengan adanya adopsi teknologi yang dilakukan oleh unit internasional roaming. Data yang digunakan bersifat data sekunder yang dikumpulkan dari aktivitas pekerjaan 
dalam perusahaan. Data yang diperoleh dari unit internasional roaming selanjutnya diolah sehingga dapat memberikan informasi yang lebih berguna terkait dampak peningkatan dari adopsi teknologi. Maintenance system merupakan hal penting yang harus selalu dilakukan oleh unit internasional roaming. Pada kajian ini maintanance system terkait dengan bentuk preventive maintenance yang dilakukan sebulan sekali dan penilaian terhadap permasalahan yang terjadi dalam rentan waktu tersebut. Seluruh permasalahan kemudian diklasifikasikan kedalam beberapa kategori yang telah disusun oleh perusahaan.

Secara umum diketahui bahwa selama 6 bulan sebelum dan sesudah nilai adopsi teknologi termasuk dalam kategori baik, sehingga adopsi teknologi tidak berdampak besar terhadap perubahan preventive maintenance. Maintanance menjadi aspek penting dalam lingkungan bisnis dimana terdapat sejumlah teknologi baru dan kemajuan dalam industri yang dapat meningkat setiap hari. Hal ini harus menjadi prioritas dalam rangka dipelihara serta agar aktivitas lancar (Lazim, 2017).

Pengukuran kedua dalam internal business process adalah development coverage state dan long term evolution (LTE). Pada dasarnya perusahaan dituntut untuk mampu mengembangkan kerjasama dengan negara lain, selain itu dengan adanya adopsi teknologi mampu meningkatkan kualitas jaringan yang semula berbasis $3 \mathrm{G}$ atau $3.5 \mathrm{G}$ menjadi $4 \mathrm{G}$. Amrullah et al. (2016) menjelaskan bahwa pengembangan bisnis yang dilakukan oleh perusahaan, pada dasarnya ditujukan untuk mendapatkan profit tambahan serta melayani pegawai lebih luas.

Adopsi teknologi yang dilakukan oleh unit internasional roaming memberikan perbedaan pertumbuhan sebelum dan sesudah. Pertumbuhan sebelum adopsi mampu menambah jumlah kerjasama sebesar 2 negara, sementara setelah adopsi mampu menambah 3 negara. Secara umum pertumbuhan tidak mampu mencapai target yang ditetapkan oleh perusahaan. Perbedaan pertumbuhan hanya tercatat berbeda 1 negara. Kondisi ini belum mengambarkan adanya perbedaan yang signifikan. Informasi lain berupa pertumbuhan kerjasama peningkatan jaringan menjadi LTE. Sebelum adopsi teknologi diketahui terjadi penambahan jaringan menjadi 3 negara dan setelah adopsi teknologi terjadi penambahan jaringan 4 negara. Secara umum terjadi peningkatan namun tidak signifikan. Kondisi ini menandakan bahwa perlu adanya pengolahan lebih lanjut untuk mengetahui adanya perbedaan nyata terhadap pertumbuhanan jumlah negara dan jaringan di buktikan pada uji beda, seperti pada Tabel 3 .

Terdapat perbedaan nyata pada pertumbuhan jumlah jaringan. Kondisi ini menandakan bahwa terdapat peluang besar untuk mengembangkan kerjasama dengan provider di negara yang telah bekerjasama dengan jaringan yang belum LTE menjadi LTE. Adopsi teknologi yang dilakukan oleh unit internasional roaming dapat dijadikan bahan bahwa akan memberikan service terbaik kepada para pelanggan. Sementara pada pengujian beda pada pertumbuhan negara tidak ditemukan perbedaan nyata, kondisi ini disebabkan karena kerjasama diawal merupakan proses bisnis yang memerlukan waktu serta keyakinan antara dua belah pihak provider.

Penilaian yang dilakukan pada internal business process dengan ketiga kriteria sangat penting dilakukan untuk mengetahui dampak dari keputusan adopsi teknologi. Manajemen pusat dapat menyatakan bahwa adopsi teknologi harus mampu mempertahankan secara konsisten aktivitas preventif maintenance. Selain itu manajemen perlu memberikan perintah kepada unit internasional roaming untuk semakin mengitensifkan promosi dalam rangka mengembangkan negara dan jaringan dengan meyakinkan provider lain bahwa PT XYZ menggunakan teknologi yang baik.

\section{c. Indikator Costumer}

Indikator costumer merupakan penilaian yang dilakukan untuk mengetahui pandangan konsumen akibat dari adopsi teknologi yang dilakukan pada unit internasional roaming. Munyanti dan Masrom (2018) memberikan penjelasan bahwa kepuasan konsumen pelanggan produk telekomunikasi dapat diuji melalui tiga faktor penting yaitu pelayanan dari pegawai dalam bentuk customer service, billing \& charges, coverage dan quality connectivity. Konsumen atau para pengguna tidak mengetahui secara pasti adanya adopsi teknologi, sehingga data yang digunakan merupakan data yang didapatkan dari hasil penyebaran jejak pendapat yang dilakukan oleh perusahaan dan bersifat data sekunder bagi penelitian. 
Tabel 3. Uji beda pada internal process sebelum dan sesudah adopsi teknologi

\begin{tabular}{lcccl}
\hline Kriteria & Sebelum & Sesudah & Asymp.Sig (Pearson Chi-Square) & Kesimpulan $(<0.05)$ \\
\hline Negara & 3.71 & 4.01 & 0.064 & Tidak terdapat perbedaan \\
Jaringan & 3.61 & 4.42 & 0.035 & Terdapat perbedaan \\
\hline
\end{tabular}

Customer intention menjadi menjadi bagian penting untuk mengetahui keinginan konsumen untuk menggunakan produk dari unit internasional roaming PT XYZ. Pengelola unit internasional roaming memberikan keterangan bahwa terdapat dua pengukuran yaitu kesesuaian dan kemudahan dalam penggunaan. Konsumen akan mencari produk telekomunikasi yang sesuai dengan kebutuhan dirinya serta kesesuaian terkait dengan biaya. Unit internasional roaming memberikan beberapa service kepada para pelanggan dengan bentuk beragam paket yang dapat digunakan diberbagai negara. Penggunaan paket roaming ditawarkan kepada pelanggan dengan menggunakan aplikasi. Adopsi teknologi yang dilakukan tidak berhubungan langsung dengan keinginan konsumen namun dalam hal ini perlu dikaji sebagai informasi umum dengan penawaran produk yang dilakukan oleh perusahaan.

Adopsi teknologi sangat terkait dengan coverage dan quality. Teknologi yang diadopsi ditujukan untuk semakin mampu untuk mengupgrade luas jangkauan serta memperbaiki koneksi pelanggan yang berada diluar negeri. Persepsi kepuasan pelanggan terkait dengan coverage sebelum adanya adopsi teknologi masih berada dibawah kategori puas, namun setelah adanya adopsi teknologi penilaian tersebut berada dalam posisi puas. Temuan ini disebabkan karena perusahaan dinilai berhasil menambah beberapa negara kerjasama serta area yang tercover oleh signal produk PT XYZ. Kualitas dari produk dijadikan kriteria untuk menilai kepuasan pelanggan hal ini disebabkan karena kualitas terkait dengan kemampuan produk memberikan pelayanan yang sesuai dengan penawaran (high speed dan selalu terkoneksi dengan baik). Pengujian dengan pendekatan statistic perlu dilakukan sebagai bentuk adanya informasi beda nyata kepuasan pelangaan, adapun informasi disajikan pada Tabel 4.

Tabel 4 menunjukan seluruh kriteria yang digunakan tidak ditemukan adanya perbedaan nyata. Kondisi ini menunjukan bahwa perusahaan harus bekerja keras untuk memberikan pelayanan kepada para pengguna produk untuk diberikan harapan. Hal ini semata untuk menjaga agar para pelanggan tetap menggunakan produk dari PT XYZ di luar negeri. Unit internasional roaming dalam hal ini perlu mencari tahu lebih dalam mengenai faktor lain yang mampu memberikan kepuasan kepada pelanggan. Menurut Widyastuti et al. (2017), kepuasan pelanggan pada perusahaan telekomunikasi dapat ditingkatkan dengan cara menambah durasi waktu respons keluhan pelanggan. Dari sisi internal proses, perusahaan dapat melakukan monitoring upaya perbaikan secara kontinyu.

\section{d. Indikator Financial}

Indikatorfinancialmenjadi indikator penting yang selalu dinilai oleh manajemen terkait dengan segala aktivitas yang dilakukan. Sitanggang et al. (2019) menjelaskan bahwa persekpektif keuangan merupakan bagian penting yang perlu dikaji untuk mengetahui hasil dari aktivitas perusahaan yang dilakukan selama beberapa waktu. Informasi terkait dengan perkembangan keuangan sebelum dan sesudah adanya adopsi teknologi dijadikan dasar untuk mengetahui perkembangan dampak keputusan yang diambil. Manajemen telah memiliki perhitungan dimana keputusan adopsi teknologi mampu mendorong pendapatan mencapai tumbuh diatas 5 persen dan terjadi pengurangan cost sebesar 10 persen.

Efficency cost merupakan ukuran yang digunakan untuk mengetahui besaran kinerja dari indikator financial pada PT XYZ diunit internasional roaming. Kriteria yang digunakan adalah pengurangan biaya pada SMS, GPRS dan voice. Pengukuran pencapaian target dibagi menjadi dua kriteria yaitu inbound dan outbound. Diketahui bahwa kedua kriteria tersebut tidak ada yang mencapai target, adapun target outbound dalam setahun adalah Rp1.200 Milliar atau Rp10 Milliar/bulan dan target inbound setahun sebesar Rp75 Milliar atau Rp6,25 Milliar/bulan. Pencapaian total inbound sebelum adopsi hanya sebesar 21,6 persen dan setelah adopsi hanya sebesar 22,8 persen. Hal ini mengindikasikan pencapain belum mencapai 50 persen dari target yang telah ditetapkan serta belum adanya peningkatan pendapatan secara signifikan. Pencapaian pada outbound sebelum adopsi sebesar 41,3 persen dan setelah adopsi teknologi sebesar 44,0 persen. Walaupun kedua kriteria tersebut menunjukan 
adanya peningkatan perlu dilakukan pengujian dengan pendekatan statistic sebagai langkah untuk mengetahui perbedaan nyata sebelum dan sesudah. Pengujian ini sebagai bentuk bahwa kebijakan dari adopsi teknologi mampu mendorong pada perubahan pendapatan bagi perusahaan. Adapun informasi pengujian disajikan pada Tabel 5.

Tabel 5 menunjukan bahwa tidak ditemukan adanya perbedaan nyata adopsi teknologi mampu memberikan dampak baik terhadap kriteria keuangan pada unit internasional roaming. Temuan ini mengindikasikan bahwa unit internasional roaming perlu dituntut untuk melakukan akselerasi dalam rangka mencapai visi misi dari perusahaan melalui keputusan adopsi teknologi baru. Pimpinan dari unit internasional roaming perlu menyusun suatu langkah kerja yang lebih baik dalam rangka mendukung arahan dari perusahaan.

\section{Implikasi Manajerial}

Manajemen dalam hal ini perlu terus melakukan identifikasi serta analisis terhadap segala perubahan yang timbul dan muncul pada bisnis telekomunikasi khususnya pada kawasan internasional. Bila manajemen mengetahui secara baik kondisi bisnis maka dampak yang didapat adalah perusahaan akan tanggap, agile dan flexible untuk menyikapi perubahan dalam dunia bisnis telekomunikasi yang begitu cepat.

Manajemen harus menggunakan secara optimal dengan melakukan penawaran produk/paket layanan roaming yang lebih kompetitif dan variatif dengan berbekal kerjasama yang sudah banyak terjalin dengan partner luar negeri baik layanan outbound maupun inbound. Penambahan kerjasama roaming service dengan partner guna meningkatkan layanan dan jaringan yang lebih luas. Memaksimalkan fitur dari teknologi baru khususnya penggunaan LTE steering untuk meningkatkan layanan dan kualitas jaringan di luar negeri. Peningkatan kualitas pemeliharaan jaringan dan layanan sebagai langkah nyata operator dalam merespons. Peningkatan kompetensi SDM PT. $\mathrm{XYZ}$ dengan menambah kegiatan training penggunaan layanan, problem handling dan bisnis analisis.

Kriteria pengukuran yang digunakan selama ini oleh manajemen PT XYZ untuk mengukur kinerja unit internasional roaming perlu diperbaiki karena hanya mengkaji kondisi keuangan perusahaan. Rekomendasi diperlukan yang bersumber dari unit internasional roaming kepada manajemen $\mathrm{PT} \mathrm{XYZ}$ sebagai dasar dalam menilai kinerja sesungguhnya, melalui penilaian yang dimulai dari sumbedaya manusia, proses bisnis dan pelanggan dapat mendorong kinerja keuangan. Manajemen perlu menyusun peta strategi yang dikhususkan pada unit internasional roaming, hal ini ditujukan sebagai bentuk mengetahui perubahan disetiap tahapnya. Implementasi ini akan berdampak semakin memperjelas proses mencapai target yang telah ditetapkan manajemen sehingga proses evaluasi dapat berjalan dengan baik serta sesuai. Selain itu, kondisi pelayanan harus disesuaikan dengan untuk mencapai kepuasan pelanggan serta mencapai kinerja keuangan yang baik. Limitasi pada penelitian ini terkait dengan penyusunan strategi, sehingga data-data yang diperoleh pada penelitian dapat digunakan untuk menyusun kuesioner dalam rangka pembobotan terkait dengan perancangan strategi terbaik untuk unit yang dijadikan objek penelitian.

Tabel 4. Uji beda pada costumer satisfaction sebelum dan sesudah adopsi teknologi

\begin{tabular}{lcccl}
\hline Kriteria & Sebelum & Sesudah & Asymp.Sig (Pearson Chi-Square) & Kesimpulan $(<0.05)$ \\
\hline Costumer Service & 3,84 & 4,14 & 0,334 & Tidak terdapat perbedaan \\
Price Fairness & 3,69 & 3,88 & 0,334 & Tidak terdapat perbedaan \\
Coverage & 3,71 & 3,84 & 0,244 & Tidak terdapat perbedaan \\
Quality & 3,67 & 3,78 & 0,242 & Tidak terdapat perbedaan \\
\hline
\end{tabular}

Tabel 5. Uji beda pada finasial sebelum dan sesudah adopsi teknologi

\begin{tabular}{lcccl}
\hline Kriteria & Sebelum & Sesudah & Asymp.Sig (Pearson Chi-Square) & Kesimpulan $(<0.05)$ \\
\hline SMS & 3,44 & 3,56 & 0,414 & Tidak terdapat perbedaan \\
Call & 3,55 & 3,72 & 0,273 & Tidak terdapat perbedaan \\
Internet & 3,58 & 3,76 & 0,323 & Tidak terdapat perbedaan \\
Inbound & 3,23 & 3,45 & 0,242 & Tidak terdapat perbedaan \\
Outbound & 3,55 & 3,61 & 0,334 & Tidak terdapat perbedaan \\
\hline
\end{tabular}




\section{KESIMPULAN DAN SARAN}

\section{Kesimpulan}

Kekuatan unit internasional roaming seperti teknologi yang baik, kerjasama dengan provider lain dan hubungan yang baik antara pegawai. Kelemahan pada unit kualitas jaringan dan kurangnya sumber daya manusia untuk mendukung bisnis. Peluang perusahaan teridentifikasi dari event dan trend penggunaan data. Ancaman untuk bisnis telekomunikasi internasional adalah pindahnya subricriber ke provider atau produk lain serta perang tarif.

Pada indikator learning \& development diketahui bahwa kriteria keamanan ditemukan adanya perbedaan nyata pada dampak dari adopsi teknologi. Hal ini menandakan perusahaan perlu meningkatkan rasa aman pada pegawai dari aktivitas adopsi teknologi yang dilakukan. Pada indikator internal business process ditemukan adanya perbedaan nyata dampak dari adopsi teknologi. Hal ini menunjukan bahwa perusahaan perlu terus menjaga serta meningkatkan pengaruh internal business process pada unit internasional roaming.

Pada indikator customer tidak ditemukan kriteria adanya perbedaan nyata dampak dari adopsi teknologi. Kondisiinimenandakan perusahaan perlumeningkatkan kinerja agar para pengguna merasa lebih nyaman dan puas. Pada indikator finansial tidak ditemukan kriteria adanya perbedaan nyata dampak dari adopsi teknologi. Hal ini menunjukan bahwa perusahaan perlu mencari cara dalam mengelola cost yang dikeluarkan serta memperbanyak para pengguna.

\section{Saran}

Saran pada penelitian ini perlu adanya suatu langkah strategis yang mampu mendorong perbaikan indikator konsumen dan finansial. Penelitian selanjutnya dapat berfokus untuk menyusun strategi terkait dengan pengembangan organisasi dari waktu ke waktu. Manajemen juga perlu menyusun peta strategi atas balanced scorecard yang telah disusun. Hal ini dalam rangka membantu meningkatkan kinerja dari unit internasional roaming. Perusahaan perlu mengevaluasi secara terus menerus dalam rangka meningkatkan dampak dari adopsi teknologi tersebut.

\section{DAFTAR PUSTAKA}

Amrullah, Hubeis M, Palupi NS. 2016. Strategi Pengembangan Bisnis Restoran Makassar Berbahan Baku Hasil Ternak dalam Mendukung Penyediaan Makanan Sehat (Studi Kasus di Restoran Marannu dan Karebosi Kelapa Gading). Journal Manajemen IKM 11(1): 1-9.

Chimtengo S, Mkandawire K, Hanif R. 2017. An evaluation of performance using the balanced scorecard model for the university of malawi's polytechnic. African journal of business management 11(4): 84-93.

Databoks. 2019. Pengguna Smartphone di Indonesia 2016-2019. https://databoks.katadata.co.id/ datapublish/2016/08/08/pengguna-smartphonedi-indonesia-2016-2019.

Decius J, Schaper N. 2017. The Competence Management Tool (CMT)-A new instrument to manage competences in small and mediumsized manufacturing enterprises. Procedia Manufacturing 9: 376-383. doi:10.1016/j. promfg.2017.04.041

Dudin MN, Vysotskaya NV, Frolova EE, Pukhart AA, Galkina MV. 2017. Improving professional competence of the staff as a strategic factor for sustainable development of companies. Journal of Business and Retail Management Research 12(1): 133-147.

Gafar TF. 2017. Manajemen perubahan dalam teknologi informasi dan komunikasi (tik) pemerintahan di indonesia sebuah pemikiran dalam menyongsong peralihan e-government menjadi e-governance. Cosmogov: jurnal ilmu pemerintahan 3(2): 153170

Getha-Taylor H, Blackmar J, Borry EL. 2016. Are competencies universal or situational? A statelevel investigation of collaborative competencies. Review of Public Personnel Administration 36(3): 306-320. doi:10.1177/0734371X15624132

Gómez-Arizaga MP, Conejeros-Solar ML, Martin A. 2016. How good is good enough? A communitybased assessment of teacher competencies for gifted students. SAGE Open 6(4): 1-14. doi:10.1177/2158244016680687.

Harumantaka D, Fahmi I, Maulana A. 2019. Perancangan sistem Pengukuran Kinerja dengan metode balanced scorecard (Studi kasus BUMD ABC Kota Bogor). Jurnal Aplikasi Manajemen dan Bisnis, 5(3): 541-551.

Hendarto AR, Prihastuty R. 2014. Resistance to change 
(studi deskriptif pada perubahan peraturan di pt. Mitra sentosa plastik industri semarang). Journal of social and industrial psychology 3 (1): 1-5.

Hidayati IY, Akbar BMB. 2019. Strategi pengembangan bisnis klinik q medical dan dengan melalui pendekatan sustainable development goals. Jurnal rekomen 3(1): 1-10.

Indriani D, Fahmi I, Yusuf AM. 2017. Perencanaan sistem evaluasi kinerja Direktorat Pemberitaan LPP-TVRI dengan pendekatan balanced scorecard (BSC). Jurnal Aplikasi Manajemen dan Bisnis 3(1): 47-58.

Iranzadeh S, Najohdeh SH, Emami NN. 2017. The impact of the implication of balanced scorecard model (bsc) in performance of the post company. Problems and Perspectives in Management 15(4): 188-196.

Kaplan RS, David PN. 2000. Balanced Scorecard: Menerapkan strategi menjadi aksi. Jakarta: Erlangga.

Kotler K.2009. Manajemen Pemasaran. Jakarta: Erlangga.

Lazim HM, Taib CA, Lamsali H, Salleh MN, Subbramaniam C. 2017. Quality-Oriented Preventive Maintenance Practices and Performance among Malaysian SMEs Manufacturing Organizations: Findings from a Survey. International Journal of Supply Chain Management 6(3): 347-359.

Munyanti I, Masrom M. 2018. Customer satisfaction factors towards mobile network services. Journal of Advanced Research in Business and Management Studies 13(1): 9-18.

Namun HS. 2015. On the applicability of analysis of internal and external factors: a case study of imam khomeini relief foundation in ardabil. International Journal of Organizational Leadership 4(1): 72-85.

Porter ME. 2008. The five competitive forces that shape strategy. Harvard Business Review 1(1): 1-18.

Pramana A. 2012. Analisis Perbandingan Trading Volume Activity Dan Abnormal Return Saham
Sebelum Dan Sesudah Pemecahan Saham [Tesis]. Semarang: Universitas Diponegoro Semarang.

Putri AB, Suhadak. 2019. Uji beda ekspor dan impor indonesia sebelum dan sesudah terjadi perang dagang amerika serikat dan china (studi pada badan pusat statistik periode september 2017september 2018). Jurnal Administrasi Bisnis 71(1): 81-90.

Riyanto S. 2018. Analisis pengaruh lingkungan internal dan eksternal terhadap keunggulan bersaing dan kinerja usaha kecil menengah (ukm) di madiun. Jurnal Manajemen Bisnis dan Inovasi 5(3): 159168.

Rocha GB, Passador CS, Shinyashiki GT. 2017. What is the social gain from competency management? The employees' perception at a Brazilian public university. Revista de Administração 52(3): 233245. doi:10.1016/j. rausp.2017.05.001

Sitanggang ED, Tulus T, NasutionBB. 2019. Analysis of satisfaction level with servqual method using artificial neural networks. Journal of Physic Conference Series 1(1): 1-11.

Subaktilah Y, Kuswardani N, Yuwanti S. 2018. Analisis swot: faktor internal dan eksternal pada pengembangan usaha gula merah tebu (Studi kasus di UKM Bumi Asih, Kabupaten Bondowoso). Jurnal Agroteknologi 12 (2): 107115.

Sugiyono. 2010. Metode Penelitian Pendidikan Pendekatan Kuantitatif, kualitatif, dan $R \& D$. Bandung: Alfabeta.

Wadha S, Parimoo D. 2016. Impact of Vision and Mision on Organizational Performance in India Context. The International Journal of Business and Management 4(12): 165-170.

Widyastuti IT, Indriana, Umar A, Bawono A. 2017. Analisis kinerja perusahaan dengan metode balanced scorecard (studi kasus PT XYZ bergerak di bidang telekomunikasi). Jurnal Administrasi dan Kesekretarisan 3(1): 124-137. 